\title{
Oxidation of arsenite to arsenate on birnessite in the presence of light
}

\author{
Samantha L. Shumlas' ${ }^{1}$ Soujanya Singireddy ${ }^{1}$, Akila C. Thenuwara' , Nuwan H. Attanayake', \\ Richard J. Reeder ${ }^{2}$ and Daniel R. Strongin ${ }^{1^{*}}$
}

\begin{abstract}
The effect of simulated solar radiation on the oxidation of arsenite $[\mathrm{As}(\mathrm{III})]$ to arsenate $[\mathrm{As}(\mathrm{V})]$ on the layered manganese oxide, birnessite, was investigated. Experiments were conducted where birnessite suspensions, under both anoxic and oxic conditions, were irradiated with simulated solar radiation in the presence of As(III) at pH 5, 7, and 9. X-ray absorption spectroscopy (XAS) was used to determine the nature of the adsorbed product on the surface of the birnessite. The oxidation of As(III) in the presence of birnessite under simulated solar light irradiation occurred at a rate that was faster than in the absence of light at $\mathrm{pH}$ 5. At pH 7 and 9, As( $\mathrm{V})$ production was significantly less than at $\mathrm{pH} 5$ and the amount of $\mathrm{As}(\mathrm{V})$ production for a given reaction time was the same under dark and light conditions. The first order rate constant $\left(\mathrm{k}_{\mathrm{obs}}\right)$ for $\mathrm{As}(\mathrm{III})$ oxidation in the presence of light and in the dark at pH 5 were determined to be 0.07 and $0.04 \mathrm{~h}^{-1}$, respectively. The $\mathrm{As}(\mathrm{V})$ product was released into solution along with $\mathrm{Mn}(\mathrm{II})$, with the latter product resulting from the reduction of $\mathrm{Mn}(\mathrm{IV})$ and/or $\mathrm{Mn}$ (III) during the As(III) oxidation process. Post-reaction XAS analysis of As(III) exposed birnessite showed that arsenic was present on the surface as As(V). Experimental results also showed no evidence that reactive oxygen species played a role in the As(III) oxidation process.
\end{abstract}

Keywords: Arsenic remediation, Birnessite, Photochemistry, As(III) oxidation

\section{Background}

The metalloid arsenic is one of the most common contaminants in ground water, where it is derived mainly from oxidative weathering of rocks [1] and from industrial effluents $[2,3]$. Arsenic in aquatic systems exists mainly in the $3+$ and $5+$ oxidation states, occurring primarily as arsenite $\left(\mathrm{H}_{3} \mathrm{AsO}_{3}\right)$ and the oxyanion arsenate $\left(\mathrm{AsO}_{4}{ }^{3-}\right)$, respectively. Although both forms pose health risks, the trivalent species is considered more toxic and more mobile than the pentavalent form [4]. The population of Bangladesh is most notably impacted by arsenic polluted drinking water with as many as 30 million of its citizens being regularly exposed [5]. Arsenic removal treatments are generally focused on reducing arsenic to acceptable levels; the World Health Organization has set

\footnotetext{
*Correspondence: dstrongi@temple.edu

1 Department of Chemistry, Temple University, 1901 N. 13th St., Philadelphia, PA 19122, USA

Full list of author information is available at the end of the article
}

a maximum allowed concentration of arsenic in drinking water at $10 \mu \mathrm{gL}^{-1}(10 \mathrm{ppb})$ [6].

Oxidation of $\mathrm{As}(\mathrm{III})$ to $\mathrm{As}(\mathrm{V})$ and then sorption to a mineral surface is a strategy that aims to convert a toxic, mobile form of As to its less mobile form, with sorption allowing for subsequent removal of the pollutant. Photochemical processes that facilitate or enhance the oxidation of trivalent arsenic have received considerable interest in recent years. Semiconductors such as $\mathrm{TiO}_{2}$ are already in use in arsenic remediation schemes, although the activation of this particular material requires ultraviolet (UV) radiation for the oxidation of As(III) [7-11]. More recent work from our laboratory has shown that the oxidation of As(III) and the adsorption of the $\mathrm{As}(\mathrm{V})$ product in part can be carried out on the iron oxyhydroxides ferrihydrite and goethite in the presence of simulated solar light $[12,13]$. Neither $\mathrm{TiO}_{2}$ nor the iron oxyhydroxides show significant activity toward As(III) oxidation in the absence of light.

Unlike $\mathrm{TiO}_{2}$ and iron oxyhydroxides, birnessite, the focus of the current study, can facilitate the oxidation of 
$\operatorname{As}(\mathrm{III})$ to $\mathrm{As}(\mathrm{V})$ in the absence of light $[4,14]$. Birnessite, a layered manganese oxide containing both $\mathrm{Mn}^{3+}$ and $\mathrm{Mn}^{4+}$ within its structure, is composed of edge sharing $\mathrm{MnO}_{6}$ octahedra arranged into stacked sheets that are separated by cations $[4,14]$. Depending on the position of the $\mathrm{Mn}^{3+}$ within the structure, triclinic or hexagonal birnessite can result. Manganese(III) that is present within the $\mathrm{MnO}_{2}$ sheet is characteristic of triclinic birnessite and the negative charge of the individual sheets is compensated by interlayer cations such as $\mathrm{Na}^{+}$ [15]. Hexagonal birnessite has $\mathrm{Mn}^{3+}$ in the interlayer above and below cation vacancies within the $\mathrm{Mn}^{4+}$ rich $\mathrm{MnO}_{2}$ sheets [16]. Interlayer regions can also contain $\mathrm{Mn}(\mathrm{II})$, other metal cations $\left(\mathrm{M}^{+} / \mathrm{M}^{2+}\right)$ and $\mathrm{H}_{2} \mathrm{O}$ [17-19]. Both of these phases of birnessite have been found to facilitate the oxidation of $\mathrm{As}(\mathrm{III})$ to $\mathrm{As}(\mathrm{V})$ in the absence of light $[4,14,20-27]$ as presented in the following composite reaction:

$$
\begin{aligned}
& \mathrm{MnO}_{2}+2 \mathrm{H}^{+}+\mathrm{H}_{3} \mathrm{As}^{\mathrm{III}} \mathrm{O}_{3}(\mathrm{aq}) \\
& \quad \rightarrow \mathrm{Mn}(\mathrm{II})(\mathrm{aq})+\mathrm{H}_{3} \mathrm{As}^{\mathrm{V}} \mathrm{O}_{4}(\mathrm{aq})+\mathrm{H}_{2} \mathrm{O}
\end{aligned}
$$

There have been a limited number of studies that have investigated the photochemical activity of birnessite, which is a small bandgap semiconductor [28-33]. We are unaware of any studies that have investigated the photochemistry of As(III) in the presence of birnessite. A brief survey of the literature shows that the band gap of birnessite has been measured in the range $1.8-2.7 \mathrm{eV}$ [33-35]. Semiconductors have a filled valence band (VB) and empty conduction band (CB), and, when irradiated with light of energy greater than or equal to the band gap, an electron in the VB is excited to the $\mathrm{CB}$, creating a hole in the VB. The resulting conduction band electron $\left(\mathrm{e}_{\mathrm{cb}}^{-}\right)$ and valence band hole $\left(\mathrm{h}_{\mathrm{vb}}^{+}\right)$can be strong reducing and oxidizing agents, respectively.

In the present study we used batch geochemical techniques to compare the As(III) oxidation rate on triclinic Na-birnessite in the presence and absence of simulated solar radiation. The oxidation was investigated under

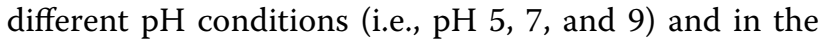
presence and absence of oxygen. X-ray absorption spectroscopy (XAS) was used to determine the oxidation state of arsenic adsorbed on the birnessite. Solution phase experiments were also conducted to help shed light on whether reactive oxygen species (ROS) contributed to the photochemistry of As(III) in the presence of birnessite.

\section{Methods}

\section{Synthesis and materials}

All the chemicals used were obtained from commercial vendors and were used without any further purification.
Nanopure deionized (DI) water $\left(18.2 \mathrm{M} \Omega \mathrm{cm}^{-1}\right)$ was used to prepare all the solutions and suspensions.

Na-birnessite used in this study was synthesized by using a modified version of the method utilized by Yang et al. [36]. Briefly, a $0.4 \mathrm{M} \mathrm{Mn}^{2+}$ solution was mixed with $8 \mathrm{M} \mathrm{NaOH}$ in $0.5 \mathrm{~L}$ of water (both solutions made in deionized/deoxygenated water), which was cooled to $0{ }^{\circ} \mathrm{C}$ and oxidized by bubbling oxygen through the solution for $5 \mathrm{~h}$. The resulting suspension was aged at $90{ }^{\circ} \mathrm{C}$ for $48 \mathrm{~h}$ with constant stirring. The resulting product was vacuum filtered and washed multiple times with deionized water. The sample was then freeze-dried [18].

\section{Characterization methods}

Synthetic birnessite was characterized using powder X-ray diffraction (XRD), Brunauer-Emmett-Teller (BET) specific surface area analysis, and transmission electron microscopy (TEM). XRD was carried out by using a Bruker AXS single crystal X-ray diffractometer with Mo $K \alpha$ radiation and a graphite monochromator. Samples were prepared by placing the sample powder into glass capillaries. The XRD pattern of Na-birnessite (Additional file 1: Figure S1) was similar to the XRD pattern of samples synthesized and used in prior studies [18, 36-40]. Typical stoichiometries obtained from these synthetic methods are reported on in prior studies [38-40].

BET surface area was measured by single-point BET $\mathrm{N}_{2}$ adsorption using an ASAP 2020 surface area analyzer from Micromeritics. The birnessite sample was degassed at $150{ }^{\circ} \mathrm{C}$ for $2 \mathrm{~h}[41,42]$. The BET surface area of Nabirnessite used for all batch experiments was determined to be $18.90 \mathrm{~m}^{2} \mathrm{~g}^{-1}$. The BET surface area of Na-birnessite used for XANES analysis was $23.10 \mathrm{~m}^{2} \mathrm{~g}^{-1}$.

Samples for TEM analysis (JEOL JEM-1400, $120 \mathrm{kV}$ ) were prepared by suspending birnessite in deionized water and sonicating for $5 \mathrm{~min}$. One drop of the suspension was deposited onto a 300 mesh carbon coated copper grid (Ted Pella, Redding, CA) and air dried. The morphology of the as-synthesized Na-birnessite particles (Additional file 1: Figure S2) was similar to the morphologies reported previously $[18,37]$. We note here that samples investigated after irradiation looked similar to those before reaction (see Additional file 1: Figure S3).

\section{Batch experiments}

All the dark and photochemical (light) experiments were conducted in a $200 \mathrm{~mL}$ water-jacketed beaker to prevent suspension heating during the $8 \mathrm{~h}$ experiments. Birnessite $(30 \mathrm{mg})$ was suspended in $148.6 \mathrm{~mL}$ of DI water, sonicated for $20 \mathrm{~min}$, and stirred for $30 \mathrm{~min}$. The $\mathrm{pH}$ of the suspension was then adjusted to $\mathrm{pH}$ 5.0, 7.0, or 9.0. Next, $1.4 \mathrm{~mL}$ of a $50 \mathrm{mM} \mathrm{As}(\mathrm{III})\left(\mathrm{NaAsO}_{2}\right)$ solution was added to the suspension, making the total concentration 
of As(III) $\sim 70 \pm 10 \mu \mathrm{M}$. For the light experiments, the suspension of interest was immediately exposed to a $900 \mathrm{~W}$ high pressure Xe lamp, with a maximum light output at wavelength of $\sim 600 \mathrm{~nm}$ [12] and a power density of $1450 \mathrm{Wm}^{-2}$ (1.45 suns). The $\mathrm{pH}$ during the reaction was monitored using a Metrohm 718 STAT Titrino and was maintained through manual $\mathrm{pH}$ adjustment that was checked every $0.5 \mathrm{~h}$. For both dark and light reactions, the suspensions were stirred throughout the experiment. Anoxic (no dissolved oxygen) batch studies were conducted by bubbling Ar gas (high purity, Airgas) though the solution of interest for $1 \mathrm{~h}$ prior to irradiation, and a constant Ar environment was maintained throughout these particular experiments. Oxic experiments were conducted in ambient air. After reaction, the birnessite suspensions from the $\mathrm{pH} 5$ light and dark reactions were centrifuged and the bulk material was washed once with pH 5 DI water then air-dried for TEM, XRD, and XAS analysis.

Ion chromatography (IC, Dionex ICS1000) was used to determine the concentration of $\mathrm{As}(\mathrm{V})$ and $\mathrm{Mn}^{2+}$ in solution during the oxidation of As(III). All aliquots of the suspension were passed through $0.22 \mu \mathrm{m}$ filters before being analyzed with IC. Only $\mathrm{As}(\mathrm{V})$ was detectable by IC. As(III) in solution was determined indirectly by adding $\mathrm{H}_{2} \mathrm{O}_{2}$ to the solution of interest (method adopted by Hansen et al. [43]), which oxidized As(III) in solution to $\mathrm{As}(\mathrm{V})$. IC of this solution yielded the total arsenic solution concentration $(\mathrm{As}(\mathrm{III})+\mathrm{As}(\mathrm{V}))$. This value along with the $\mathrm{As}(\mathrm{V})$ concentration associated with the solution prior to oxidation was used to obtain the As(III) concentration prior to oxidation. Total adsorbed arsenic on birnessite was determined by subtracting the total arsenic present in solution (after $\mathrm{H}_{2} \mathrm{O}_{2}$ addition) from the known concentration of As(III) added initially.

\section{Detection of reactive oxygen species (ROS)}

The possibility of hydroxyl radical $(\mathrm{OH} \cdot)$ generation during the photochemical reactions was investigated with a fluorescence method using coumarin $[44,45]$. The reaction of coumarin with hydroxyl radical yields 7-hydroxycoumarin, which gives a distinctive fluorescence peak at $460 \mathrm{~nm}$ upon excitation at $332 \mathrm{~nm}$. Our experimental protocol involved the addition of coumarin to the reaction system to achieve a concentration of $1 \mathrm{mM}$ prior to irradiation. Samples were then obtained at fixed times and they were analyzed in a fluorometer (Photon Technology International spectrometer) using $332 \mathrm{~nm}$ excitation radiation.

The addition of mannitol to certain reaction solutions was also carried out to supplement the coumarin studies. Prior studies have shown that mannitol is an effective scavenger of $\mathrm{OH}$ - and oxidative holes formed during the irradiation of semiconductor materials [46]. In these particular experiments, $20 \mathrm{mM}$ mannitol was added to specific reaction mixtures of birnessite and As(III) and the effect of the mannitol addition on product formation was investigated under both light and dark conditions.

The possible presence of hydrogen peroxide in reaction solutions was investigated with an analytical technique that involved the use of $3^{\prime}$-( $p$-amino phenyl) fluorescein (APF) and Horseradish peroxidase (HRP) in a phosphate buffer ( $\mathrm{pH}$ 7.4) [47]. The technique is based on the ability of HRP to catalyze the oxidation of APF by $\mathrm{H}_{2} \mathrm{O}_{2}$. The oxidized product exhibited fluorescence at $515 \mathrm{~nm}$ (excitation wavelength, $490 \mathrm{~nm}$ ). The detection of $\mathrm{H}_{2} \mathrm{O}_{2}$ was carried out in an ex situ manner. Aliquots of the solution were periodically withdrawn from the system of interest and added to a buffered solution containing $10 \mu \mathrm{M}$ APF and $0.2 \mu \mathrm{M}$ HRP. An ex situ measurement was necessary for $\mathrm{H}_{2} \mathrm{O}_{2}$ detection, since in situ control experiments showed that exposure of the APF and HRP to light led to erroneous results, presumably due to the instability of HRP during irradiation.

Experiments were carried out to measure short-lived reactive oxygen species using electron paramagnetic resonance spectroscopy (EPR). Spectra were recorded at room temperature using a Bruker EMX-200R spectrometer at a microwave frequency of $3.65 \mathrm{GHz}$. Samples were prepared ex situ and then placed in a capillary tube inside of a quartz EPR tube for light irradiation. A fiber optic cable was used to irradiate the sample through the photolysis port on the EPR cavity. For in situ experiments a $10 \mathrm{~mL}$ aliquot was sampled out of the prepared batch experiment to which a spin trap was added (5,5-dimethyl-1-pyrroline- $\mathrm{N}$-oxide, DMPO). Once in the EPR cavity, a dark spectrum was acquired and then the light was turned on. Successive scans were taken every $15 \mathrm{~min}$ for $1 \mathrm{~h}$ total. Experimental parameters included an attenuation of $5.0 \mathrm{~dB}$, modulation frequency of $100 \mathrm{kHz}$, a modulation amplitude of $15 \mathrm{G}$, sweep time $20.97 \mathrm{~s}$, receiver gain $2 \times 10^{4}$. Data processing was done with Bruker software (WINEPR).

\section{X-ray absorption spectroscopy (XAS)}

Arsenic K-edge X-ray absorption near-edge structure (XANES) spectroscopy was used to determine the average oxidation state of the arsenic sorbed on birnessite. In previous work from our laboratory [13], we showed that X-ray beam-induced oxidation of As(III) can be avoided by using quick-scanning X-ray absorption spectroscopy, as implemented at beamline X18B at the National Synchrotron Light Source, Brookhaven National Laboratory $[13,48,49]$.

XANES spectra of As-reacted birnessite samples in the current study were collected over a duration of $30 \mathrm{~s}$ using 
the quick-scanning technique, with each scan requiring less than $1 \mathrm{~s}$. As(III)-reacted samples were sealed between two layers of Kapton tape, and mounted at $45^{\circ}$ relative to the incident X-ray beam. XANES spectra were measured in fluorescence mode, using a passivated implanted planar silicon detector. For each sample, the spectra within a sequence were compared to confirm the absence of any changes during scanning and then the first 3-5 spectra were averaged to achieve better signal/noise. A linear pre-edge background function was subtracted from the averaged spectrum, and normalization was performed at an energy value above the absorption edge $(11,915 \mathrm{eV})$, as described by Bhandari et al. [50]. XANES spectra of $\mathrm{As}(\mathrm{III})$ and $\mathrm{As}(\mathrm{V})$ aqueous solutions were used as oxidation state references. The position of the absorption maximum for $\mathrm{As}(\mathrm{V})$ was found to be shifted $\sim 3.5 \mathrm{eV}$ higher than the position for the As(III) solution.

\section{Results and discussion}

Effect of light on the redox chemistry of As(III) on birnessite Aqueous $\mathrm{As}(\mathrm{V})$ product

Figure 1 exhibits the solution phase concentration of $\mathrm{As}(\mathrm{V})$ as a function of time at $\mathrm{pH} 5$ and 7 during the individual exposure of birnessite to $470 \mu \mathrm{M}$ As(III) under dark and light conditions, and under anoxic and oxic solution conditions. We mention that control experiments (Additional file 1: Figure S4), where aqueous As(III) was exposed to light for $8 \mathrm{~h} \mathrm{(pH} 5$ and 7) in the absence of birnessite, showed no detectable As $(\mathrm{V})$ product. This result taken together with data from Fig. 1 indicates that the photochemical oxidation of As(III) to $\mathrm{As}(\mathrm{V})$ in these experiments does not occur unless birnessite is present.

Analysis of the data presented in Fig. 1 shows that the amount of solution phase $\mathrm{As}(\mathrm{V})$ oxidation product was not a function of the dissolved oxygen level during the light-exposure for a particular solution $\mathrm{pH}$. In the presence of dissolved oxygen at $\mathrm{pH} 5,136 \mu \mathrm{M}$ of $\mathrm{As}(\mathrm{V})_{(\mathrm{aq})}$ product formed after $8 \mathrm{~h}$ under dark conditions and $197 \mu \mathrm{M}$ of $\mathrm{As}(\mathrm{V})$ was produced when the reacting system was exposed to light for $8 \mathrm{~h}$. The As(V) concentrations after $8 \mathrm{~h}$ are similar for the oxic and anoxic experiments in the presence of light (197 and $196 \mu \mathrm{M}$, respectively) and also similar in the dark experiments (136 and $147 \mu \mathrm{M}$, respectively). These results show that light irradiation has a greater influence on the oxidation As(III) and oxygen does not appear to play a major role in the oxidation mechanism.

The total arsenic in solution did not change significantly over the course of the experiment, indicating that As did not sorb to the surface at an experimentally observable amount. Based on the As(III) loss from solution, which was determined by subtracting the $\mathrm{As}(\mathrm{V})$

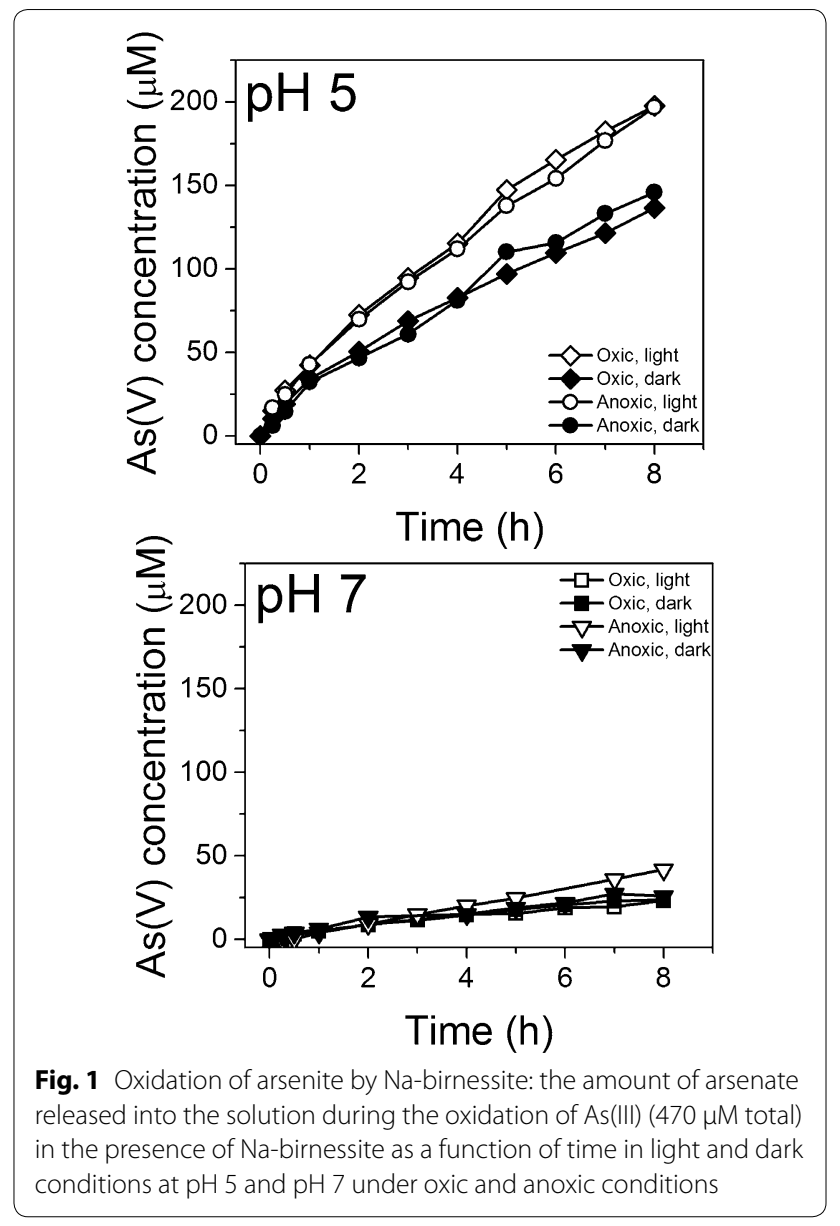

produced over time from the amount of As initially added $(470 \mu \mathrm{M})$, we calculate the first order rate constant $\left(\mathrm{k}_{\mathrm{obs}}\right)$ for As(III) oxidation to be 0.07 and $0.04 \mathrm{~h}^{-1}$, respectively, under light and dark conditions (dissolved oxygen was present). We point out that the measured $\mathrm{k}_{\mathrm{obs}}$ in our dark experiment at pH $5\left(0.04 \mathrm{~h}^{-1}\right)$ is higher than the $\mathrm{k}_{\mathrm{obs}}\left(0.02 \mathrm{~h}^{-1}\right)$ reported previously by Tournassat et al. [27], using a crystalline hexagonal birnessite at $\mathrm{pH}$ 5. One likely reason for this discrepancy is the nature of the birnessite samples, since significant variations can occur depending of the crystallinity, average oxidation state, vacancy concentration and morphology of the birnessite used. Also, the As:Mn ratio used in our experiment (0.22) was lower than in the prior study (0.44).

Upon raising the $\mathrm{pH}$ of the reaction medium to 7 and 9 (Additional file 1: Figure S5) the amount of $\mathrm{As}(\mathrm{V})$ produced decreased relative to the amount of $\mathrm{As}(\mathrm{V})$ produced at $\mathrm{pH} 5$ at the same birnessite loading. The amount of $\mathrm{As}(\mathrm{V})$ produced at $\mathrm{pH} 7$ in the presence of light $(23 \mu \mathrm{M})$ is approximately 0.1 times less than the amount experimentally observed at $\mathrm{pH} 5$ in the presence of light $(197 \mu \mathrm{M})$. At $\mathrm{pH} 9$, the amount of $\mathrm{As}(\mathrm{V})$ produced over 
time is below the detection limit of the chromatographic method used to analyze for As $(\mathrm{V})$. The final $\mathrm{As}(\mathrm{V})$ concentration after $8 \mathrm{~h}$ is presented in Table 1 . The lower As(III) oxidation rate at higher $\mathrm{pH}$ conditions has been observed by others, and it is often attributed to the passivation of the birnessite surface by either manganese(II) or (III) [23, 25-27, 51, 52]. Also we note that the effect of light seems to be absent at these higher $\mathrm{pH}$ conditions, which could be due to this surface passivation.

The general shape of the $\mathrm{As}(\mathrm{V})$ versus time plots (Fig. 1) associated with the photochemical system is qualitatively similar to the dark reaction. In particular, both reaction systems show an $\mathrm{As}(\mathrm{V})$ formation rate that decreases over time. Prior studies of the dark reaction system generally attributed this decrease to the passivation of the birnessite surface by $\mathrm{Mn}(\mathrm{III})$, derived from the reduction of two $\mathrm{Mn}(\mathrm{IV})$ species to $\mathrm{Mn}$ (III) by As(III) with the concomitant formation of $\operatorname{As}(\mathrm{V})[4,23,53]$ :

$$
\begin{aligned}
& 2 \mathrm{MnO}_{2}+\mathrm{H}_{3} \mathrm{AsO}_{3}+\mathrm{H}_{2} \mathrm{O} \\
& \quad \rightarrow 2 \mathrm{MnOOH}+\mathrm{H}_{2} \mathrm{AsO}_{4}^{-}+\mathrm{H}^{+}
\end{aligned}
$$

More recent studies, however, show strong evidence that at early reaction times the primary reaction product is $\mathrm{Mn}(\mathrm{II})$, resulting from the 2-electron reduction of $\mathrm{Mn}(\mathrm{IV})$ by $\mathrm{As}(\mathrm{III})$ [51]:

$$
\begin{aligned}
& \mathrm{MnO}_{2}+\mathrm{H}_{3} \mathrm{AsO}_{3}+\mathrm{H}^{+} \\
& \quad \rightarrow \mathrm{Mn}(\mathrm{II})+\mathrm{H}_{2} \mathrm{AsO}_{4}^{-}+\mathrm{H}_{2} \mathrm{O}
\end{aligned}
$$

It has been proposed that the primary buildup of $\mathrm{Mn}(\mathrm{III})$, which leads to passivation of the surface, results from the comproportionation reaction between $\mathrm{Mn}$ (II) product and surface $\mathrm{Mn}(\mathrm{IV})$ to produce $\mathrm{Mn}(\mathrm{III})[54,55]$. This increase in $\mathrm{Mn}(\mathrm{III})$ is evidenced by the transformation of triclinic birnessite to hexagonal birnessite (Additional file 1: Figure S6) [56], which is caused by migration of $\mathrm{Mn}$ (III) within the sheet to the interlayer region [39]. The oxidation of $\mathrm{As}$ (III) by surface $\mathrm{Mn}(\mathrm{III})$ is considered to be slow, consistent with the decreasing rate of $\mathrm{As}(\mathrm{V})$ formation as the reaction time increases $[23,51]$.

We conducted an additional experiment to show that light continues to enhance the rate of $\mathrm{As}(\mathrm{V})$ production at reaction times where passivation of the birnessite surface has occurred (Fig. 2). In this experiment,

Table $1 \mathrm{As}(\mathrm{V})$ in solution after $8 \mathrm{~h}$ at $\mathrm{pH} \mathrm{5,} \mathrm{7,} \mathrm{and} 9$

\begin{tabular}{lllllll}
\hline & pH 5 & pH 5 & pH 7 & pH 7 & pH 9 & pH 9 \\
Light & Dark & Light & Dark & Light & Dark \\
\hline Oxic & 197 & 136 & 23 & 23 & - & 6 \\
Anoxic & 196 & 145 & 43 & 25 & 13 & - \\
\hline
\end{tabular}

Concentrations are given in $\mu \mathrm{M}$

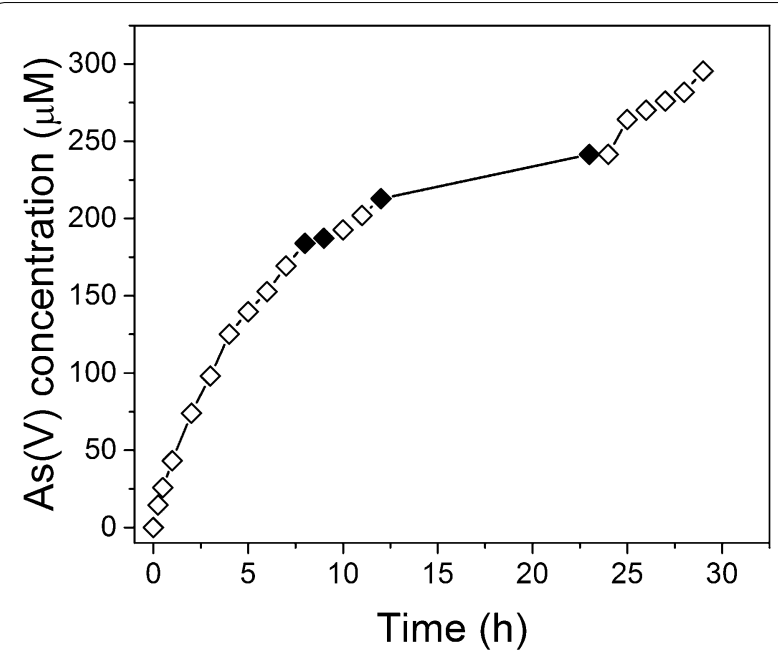

Fig. 2 On/off cycling of light effects on As(III) oxidation: As(V) production resulting from a As(III)/birnessite suspension at $\mathrm{pH} 5$ under oxic conditions. The open symbols indicate times that the suspension was exposed to light and the closed symbols indicate times where the light was turned off. Even at relatively long reaction times light enhances the formation rate of $\mathrm{As}(\mathrm{V})$

conducted at $\mathrm{pH} 5$, an $\mathrm{As}(\mathrm{III}) /$ birnessite suspension was first exposed to light, and was followed by two off/ on light cycles (indicated in the figure). The experimental strategy here was to best compare the rate of $\mathrm{As}(\mathrm{V})$ formation under light and dark conditions at extended reaction times. Analysis of the slopes associated with the plot during the light-off and light-on cycles shows that the rate of $\mathrm{As}(\mathrm{V})$ formation on the passivated birnessite is enhanced by a factor of 2.3 in the presence of light (relative to the dark data). In particular, the rate of $\mathrm{As}(\mathrm{V})$ production for the $8-10 \mathrm{~h}$ period (light off cycle) was $4.34 \mu \mathrm{M} \mathrm{h}^{-1}\left(12.52 \mu \mathrm{M} \mathrm{h}^{-1} \mathrm{~m}^{-2}\right)$, and this rate increased to $10.07 \mu \mathrm{M} \mathrm{h}^{-1}\left(29.07 \mu \mathrm{M} \mathrm{h}^{-1} \mathrm{~m}^{-2}\right)$ for the $10-12 \mathrm{~h}$ period when the sample was exposed to light. In the second light off/on cycle, the $\mathrm{As}(\mathrm{V})$ formation rate was $2.39 \mu \mathrm{M} \mathrm{h}^{-1}\left(6.91 \mu \mathrm{M} \mathrm{h}^{-1} \mathrm{~m}^{-2}\right)$ for the 12-24 h light-off period and increased to $10.76 \mu \mathrm{M} \mathrm{h}^{-1}\left(31.07 \mu \mathrm{M} \mathrm{h}^{-1} \mathrm{~m}^{-2}\right)$ for the 24-29 $\mathrm{h}$ light-on interval. While the rate of As(III) oxidation decreases over the course of time in the dark due to changes to the birnessite surface structure, exposure of the system to light still leads to an enhancement of As(III) oxidation rate relative to dark conditions. We come back to a brief discussion of this experimental observation later.

\section{Adsorbed product on birnessite under dark and light conditions}

During the course of the experiment, there was no major change to the total arsenic present in solution, therefore, a quantifiable amount of adsorbed product could not be 
determined in the aqueous batch reactions. This lack of quantifiable adsorbed arsenic could be due to the $\mathrm{Na}$ birnessite sample possessing a small concentration of cation vacancies, which is the favored site for metal ions to sorb $[39,57]$. This observation agrees with a recent study that investigated As(III) oxidation on different manganese oxides in which the experimental observation that crystalline triclinic birnessite did not adsorb observable amounts of As was also made [14]. Results from a different batch of Na-birnessite synthesized in our laboratory exhibited a higher surface area (HSA birnessite, $23.10 \mathrm{~m}^{2} \mathrm{~g}^{-1}$ ) and led to an increased amount of As(V) adsorption during the As(III) oxidation reaction. We note that while the two different Na-birnessite samples showed differences in $\mathrm{As}(\mathrm{V})$ adsorption, both samples showed an enhancement in As(III) oxidation rate when exposed to light (data for HSA birnessite, shown in Additional file 1: Figure S7).

Arsenic K-edge XANES spectra presented in Fig. 3 indicate that the primary adsorbed product on the HSA birnessite after exposure to As(III) for $8 \mathrm{~h}$ is $\mathrm{As}(\mathrm{V})$ whether the reaction occurs in the absence or presence of light. In particular, the energy of the main peak in the XANES for all birnessite samples that were exposed to As(III) under all experimental conditions is identical to the value for the reference $\mathrm{As}(\mathrm{V})$ solution sample. This result is consistent with prior studies that have shown that $\mathrm{As}(\mathrm{III})$ oxidizes to $\mathrm{As}(\mathrm{V})$ on birnessite under dark conditions $[4,26,27]$. Our data show that under light conditions, $\operatorname{As}(\mathrm{V})$ is also the primary adsorbed product when birnessite is exposed to As(III).

\section{Mn(II) product}

Figure 4 exhibits the concentration of $\mathrm{Mn}$ (II) product in solution as a function of time during the As(III) oxidation reaction ( $\mathrm{pH}$ of 5$)$ in the absence and presence of light for oxic and anoxic conditions. The amount of $\mathrm{Mn}$ (II) partitioning into solution is higher in the presence of light than in the dark. After $7 \mathrm{~h}$ of reaction (under oxic conditions), the concentration of dissolved $\mathrm{Mn}(\mathrm{II})$ is 137 and $109 \mu \mathrm{M}$, in the light and dark experiments, respectively. Using these $\mathrm{Mn}(\mathrm{II})$ data along with the concentration of oxidized As(III) (i.e., As(V) $)_{\mathrm{aq}}+\mathrm{As}(\mathrm{V})_{\mathrm{ads}}$ ) we calculate $\mathrm{Mn}(\mathrm{II})_{(\mathrm{aq})}: \operatorname{As}(\mathrm{V})$ ratios of $0.75: 1$ and $0.90: 1$ for the light and dark experiments, respectively. The ratio associated with the dark reaction is close to the 1:1 stoichiometry associated with Eq. 1, whereas the ratio for the irradiated sample is lower. The difference could be due to the oxidation of $\mathrm{Mn}^{2+}$ to insoluble $\mathrm{Mn}$ (III) or $\mathrm{Mn}(\mathrm{IV})$ species in the presence of dissolved oxygen and light or the formation of ternary complexes containing $\mathrm{Mn}^{2+}$ and $\mathrm{As}(\mathrm{V})$ in the presence of light [25]. We note that control experiments, where birnessite suspensions in the absence of $\mathrm{As}(\mathrm{III})$ at $\mathrm{pH} 5.0$ were irradiated, showed no detectable aqueous $\mathrm{Mn}(\mathrm{II})$ product. Also $\mathrm{Mn}$ (II) release at $\mathrm{pH}$ 7 and 9 was not experimentally observed in our studies, presumably due to the tendency of $\mathrm{Mn}$ (II) to stay surface bound at these higher $\mathrm{pH}$ conditions [26].
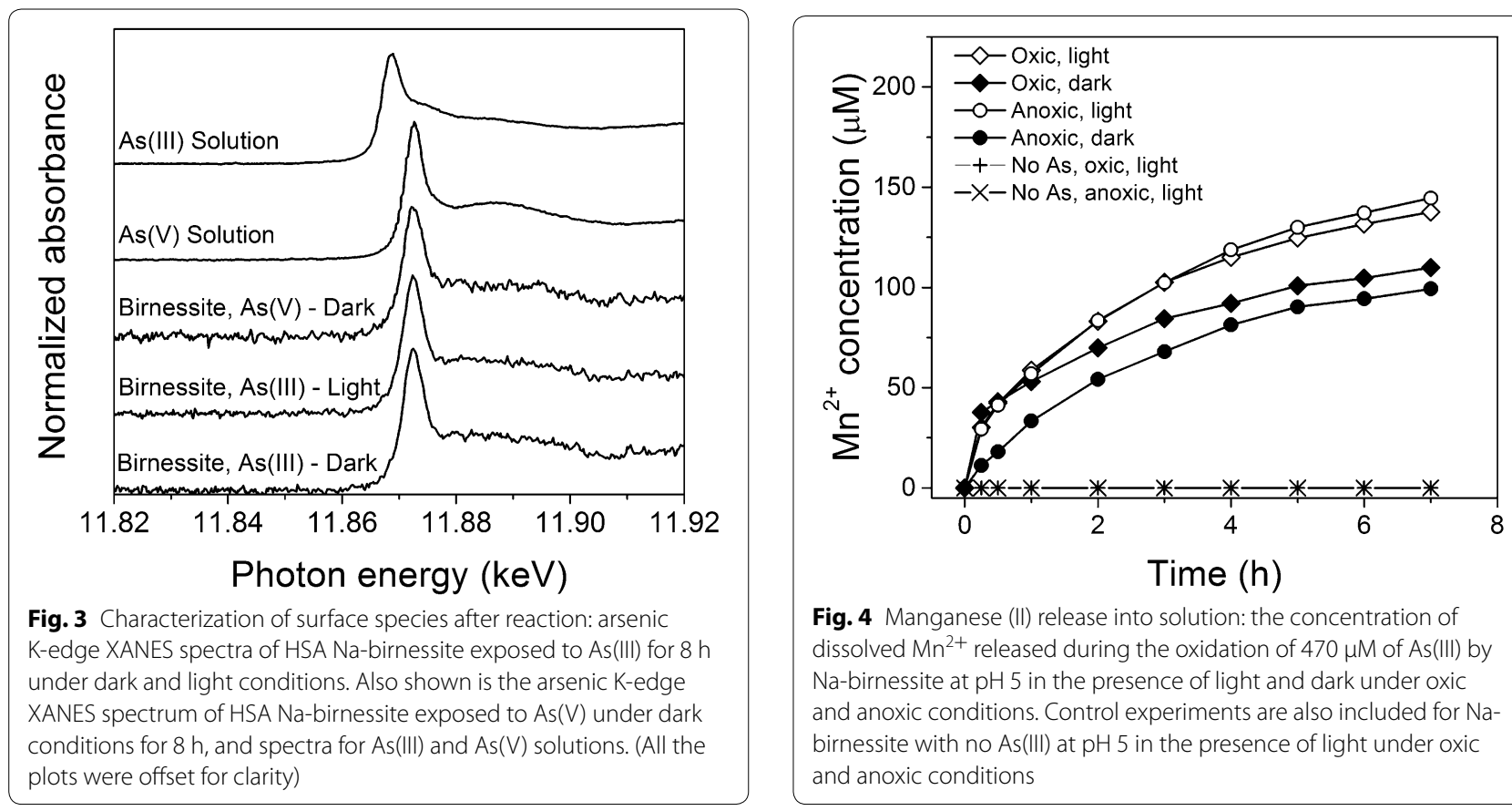

Fig. 4 Manganese (II) release into solution: the concentration of dissolved $\mathrm{Mn}^{2+}$ released during the oxidation of $470 \mu \mathrm{M}$ of As(III) by $\mathrm{Na}$-birnessite at $\mathrm{pH} 5$ in the presence of light and dark under oxic and anoxic conditions. Control experiments are also included for Nabirnessite with no As(III) at pH 5 in the presence of light under oxic and anoxic conditions 


\section{Mechanistic aspects of As(III)/birnessite photochemistry}

Relative to the reaction of As(III)/birnessite in the dark, the photochemistry of As(III)/birnessite system brings forward additional reaction pathways via the production of reducing $\mathrm{e}_{\mathrm{cb}}^{-}$and oxidizing $\mathrm{h}_{\mathrm{vb}}^{+}$. With regard to the reducing conduction band electrons, prior research has shown that the irradiation of $\mathrm{MnO}_{2}$ in the aqueous environment results in the release of $\mathrm{Mn}(\mathrm{II})$, redox chemistry that can be expressed by the following composite reaction $[34,58]$ :

$$
\mathrm{MnO}_{2}+4 \mathrm{H}^{+}+2 \mathrm{e}_{\mathrm{cb}}^{-} \rightarrow \mathrm{Mn}(\mathrm{II})+2 \mathrm{H}_{2} \mathrm{O}
$$

Furthermore, studies have generally studied the production of $\mathrm{Mn}(\mathrm{II})$ photoproduct during the irradiation of manganese oxides in the presence of electron donors (e.g., organic species) that are oxidized by the photogenerated $h_{\mathrm{vb}}^{+}$. Interestingly, recent studies have also shown that the photogeneration of $\mathrm{Mn}$ (II) during the irradiation of birnessite can occur in an ice matrix in the absence of an electron donor (other than potentially water) [58], albeit at a much lower rate than if an electron donor was present. Recent studies investigated the photochemistry of birnessite with time-resolved XAS during the irradiation of the material with $400 \mathrm{~nm}$ light in water [59]. This particular study showed that the photogenerated electrons resulted in the reduction of $\mathrm{Mn}$ (IV) to $\mathrm{Mn}$ (III) that migrated into the interlayer region of the layered birnessite. It was speculated in this study that the oxidative hole could lead to the generation of reactive oxygen species such as hydroxyl radical, but their potential reaction to form $\mathrm{H}_{2} \mathrm{O}_{2}$ would only lead to the oxidation of $\mathrm{Mn}(\mathrm{III})$ back to $\mathrm{Mn}(\mathrm{IV})$ [59].

In the present study we suspect that the oxidative hole formed in the valence band of birnessite during irradiation was directly responsible for the oxidation of As(III). In short, our results do not give support to a scenario where ROS formed during the irradiation of birnessite in the presence or absence of As(III). Experiments were carried out that used both fluorescent probes and EPR (coupled with trapping agents) to investigate the production of ROS. To investigate the generation of hydroxyl radical, a fluorescence method using coumarin was employed [44, 45]. The reaction of coumarin with hydroxyl radical forms a fluorescent adduct with a unique emission. Data obtained using this method in situ (Additional file 1: Figure S8) did not show evidence for the presence of the adduct. We also used the APF-HRP test (see experimental) to detect hydrogen peroxide in solution, but also found no evidence for this species (Additional file 1: Figure S9). We point out, however, that if $\mathrm{H}_{2} \mathrm{O}_{2}$ was produced it might be expected to rapidly decompose in the presence of birnessite [60-62].
In addition to fluorescent-based probes, EPR experiments were carried out to further investigate the possibility of ROS generation. These particular experiments using DMPO as a spin-trapping agent for hydroxyl radical did not yield any support for the generation of this particular radical. Whether the experiment was carried out on an aqueous suspension of birnessite or suspension of birnessite in the presence of As(III), the resulting spectra could be associated with the characteristic EPR spectrum for Mn(II) (Additional file 1: Figures S10, S11). Consistent with our batch studies the magnitude of the $\mathrm{Mn}$ (II) spectral weight from the EPR experiment was greater when As(III) was present, compared to the irradiation of birnessite in As(III)-free water (Additional file 1: Figure S11). We attribute the increased Mn(II) signal to the presence of the electron donor (i.e., As(III)) that can be oxidized by the valence hole.

To better determine whether As(III) oxidation occurred in part due to the presence of valence band holes in the presence of light, we carried out experiments that utilized mannitol. Prior studies have shown that mannitol is an efficient scavenger of $\mathrm{OH}$. and oxidative holes [46]. Figure 5 shows data from an experiment where $20 \mathrm{mM}$ mannitol was added to particular reaction mixtures. It is mentioned that both the coumarin-based analytical technique and EPR studies strongly suggest that solution $\mathrm{OH} \cdot$ is not an important intermediate species when birnessite was irradiated in the absence or presence of As(III). Hence, we attribute mannitolinduced changes in the rate of production of $\mathrm{As}(\mathrm{V})$ in the

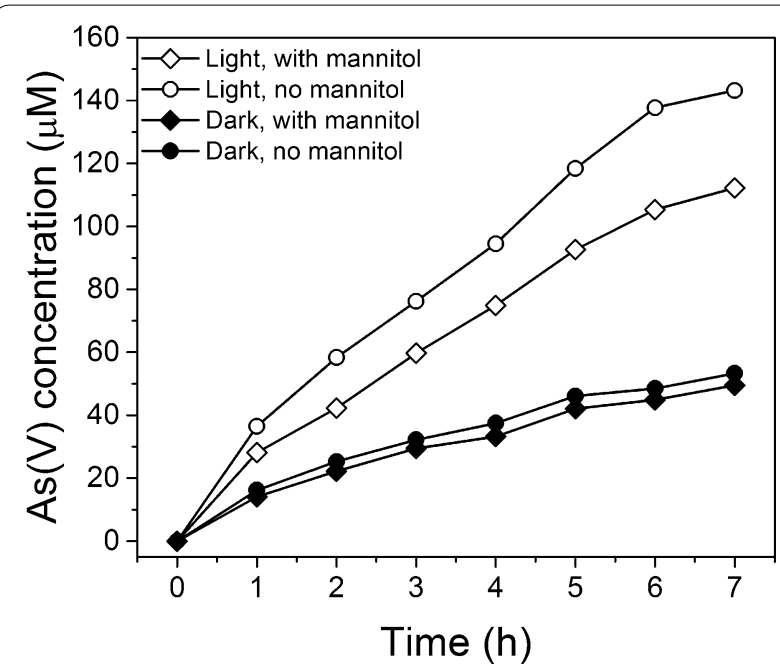

Fig. 5 Effect of mannitol on the oxidation of arsenite by Na-birnessite: concentration of aqueous $\mathrm{As}(\mathrm{V})$ released into the solution during the oxidation of $\mathrm{As}$ (III) in the presence of Na-birnessite at pH 5 (oxic) under light and dark conditions with and without mannitol 
presence of As(III), birnessite, and light to the scavenging of oxidative holes (or $\mathrm{OH}$. formed through the oxidation of surface hydroxyl groups). It should be noted that the data show that the addition of mannitol, even at the relatively high concentration of $20 \mathrm{mM}$, does not affect $\mathrm{As}(\mathrm{V})$ product formation in the dark. We infer from this result that mannitol does not block birnessite sites that can oxidize $\mathrm{As}(\mathrm{III})$ to $\mathrm{As}(\mathrm{V})$ in the absence of light. In the photo-reaction data, the presence of mannitol results in an $\mathrm{As}(\mathrm{V})$ concentration that is approximately $30 \%$ lower relative to the mannitol-free system after $7 \mathrm{~h}$. We infer from this result that mannitol is scavenging photogenerated holes (that oxidize mannitol) that would otherwise oxidize As(III).

The mechanism by which $\mathrm{As}(\mathrm{III})$ is oxidized to $\mathrm{As}(\mathrm{V})$ photochemically is not entirely clear. One possible reaction sequence would be the oxidation of As(III) via two one-electron transfer steps as described by the following reactions $[63,64]$ :

$$
\begin{aligned}
& \mathrm{h}_{\mathrm{vb}}^{+}+\mathrm{As}(\mathrm{III}) \rightarrow \mathrm{As}(\mathrm{IV}) \\
& \mathrm{h}_{\mathrm{vb}}^{+}+\mathrm{As}(\mathrm{IV}) \rightarrow \operatorname{As}(\mathrm{V})
\end{aligned}
$$

If such a mechanism were operative it might be expected to exhibit rapid kinetics, since prior studies have shown that the reaction of As(IV) with dissolved $\mathrm{O}_{2}$ is a rapid reaction that leads to $\mathrm{As}(\mathrm{V})$ [65]. We, however, do not observe a dependence of the photochemical $\mathrm{As}(\mathrm{V})$ production rate on the presence of dissolved oxygen. It is conceivable that a species such as $\mathrm{H}_{2} \mathrm{O}_{2}$ could play a role in the oxidation of $\mathrm{As}(\mathrm{III})$ to $\mathrm{As}(\mathrm{V})$. If a short lived $\mathrm{H}_{2} \mathrm{O}_{2}$ ROS does play a role, it would be expected to form from chemistry initiated by the valence band hole and the oxidation of surface hydroxide [59]. Formation pathways via the reduction of dissolved oxygen do not appear to be a possibility, because of the aforementioned insensitivity of photochemical As(III) oxidation to dissolved oxygen. Whether this pathway is inhibited due to the reduction potential of oxygen lying higher than the conduction band minimum of birnessite, or to the efficiency of $\mathrm{Mn}(\mathrm{IV})$ [or $\mathrm{Mn}(\mathrm{III})$ ] as an electron acceptor (to form $\mathrm{Mn}$ (III) and $\mathrm{Mn}$ (II), respectively) cannot be discerned from our results.

It is interesting that the photochemical oxidation of As(III) still occurs with a significant rate even when As(III) oxidation in the dark has decreased significantly after $20 \mathrm{~h}$ of reaction (Fig. 2). Most prior studies have shown for the dark reaction between As(III) and birnessite that the surface becomes covered with $\mathrm{Mn}$ (III) [23, $25-27,52,54]$. It is conceivable that the irradiation of such a surface might not directly oxidize As(III) through valence band hole formation, but instead the oxidation of a fraction of $\mathrm{Mn}(\mathrm{III})$ species back to $\mathrm{Mn}(\mathrm{IV})$ by the hole could occur. As(III) oxidation on such newly created $\mathrm{Mn}(\mathrm{IV})$ sites would be expected to occur with faster kinetics than on Mn(III) sites [51]. The exact role of these species in the photochemistry of birnessite has significant implications in environmental manganese cycling. Understanding the mechanistic aspects of this chemistry warrants future study.

\section{Conclusions}

We have shown that the oxidation of As(III) by Na-birnessite can be enhanced via irradiation with simulated solar light (at a solution $\mathrm{pH}$ of 5). The simulated light intensity used in this study is comparable to the light intensity experienced by the Earth's surface environment (i.e., 1.45 suns). The photochemical pathways presented in this contribution are informed by the many prior studies that have investigated the adsorption and oxidation of As(III) on birnessite $[4,14,23-27]$ under dark conditions. We propose that the creation of the hole-electron pair during the irradiation of the small band-gap semiconductor drives the oxidation chemistry; the valence band hole leads to the oxidation of As(III) and the conduction band electron leads to the reduction of $\mathrm{Mn}(\mathrm{IV}) / \mathrm{Mn}$ (III) and the formation of $\mathrm{Mn}(\mathrm{II})$ product. The results of this study have environmental implications, most notably that the birnessite-facilitated oxidation of mobile $\mathrm{As}(\mathrm{III})$ to the less mobile $\mathrm{As}(\mathrm{V})$ at appropriate $\mathrm{pH}$ conditions $(\mathrm{pH} 5$ in our study) can be facilitated by photochemical means. Such a process could potentially be useful for a more efficient remediation of arsenic in environments where birnessite can absorb photons having a requisite energy. Future work that investigates the photochemistry of hexagonal birnessite would give insights on the effect that birnessite phase and crystallinity has on this chemistry as well.

\section{Additional file}

Additional file 1. Supporting information showing the XRD of birnessite, TEM images of birnessite, control experiments of As(III) irradiated in the absence of birnessite, $\mathrm{pH} 9$ batch reaction data, post-reaction TEM images of birnessite, data relevant to the detection of $\mathrm{OH}$ and $\mathrm{H}_{2} \mathrm{O}_{2}$, and EPR data for As(III)/birnessite.

\section{Authors' contributions}

SLS, SS, ACT and NHA conducted batch reaction experiments and analyzed the samples. RJR collected and processed XAS data and helped prepare the XAS section of the manuscript. SLS, SS and DRS prepared the rest of the manuscript. DRS oversaw this project and helped develop the experiments. All authors read and approved the final manuscript.

\section{Author details}

${ }^{1}$ Department of Chemistry, Temple University, 1901 N. 13th St., Philadelphia, PA 19122, USA. ${ }^{2}$ Department of Geosciences, Stony Brook University, Stony Brook, NY 11794, USA. 


\section{Acknowledgements}

The authors like to acknowledge Brookhaven National laboratory for using the National Synchrotron Light Source, which was supported by the US Department of Energy, Office of Science, Office of Basic Energy Sciences, under grant \# DE-AC02-98CH10886. The authors also thank Dr. Michael J. Zdilla (Department of Chemistry, Temple University) for providing access to the XRD and EPR.

\section{Competing interests}

The authors declare they have no competing interests.

Received: 21 June 2016 Accepted: 21 September 2016

Published online: 06 October 2016

\section{References}

1. Scott M (1991) In kinetics of adsorption and redox processes on iron and manganese oxides: reactions of As(III) and Se(IV) at goethite and birnessite surfaces. California Institute of Technology, Pasadena

2. Moore JW, Ramamoorthy S (1984) Heavy metals in natural waters. Springer-Verlag, Berlin

3. Ng JC, Moore MR (2005) Arsenic in drinking water: a natural killer in Bangladesh and beyond. Med J Aust 183(11-12):562-563

4. Manning BA, Fendorf SE, Bostick B, Suarez DL (2002) Arsenic(III) oxidation and arsenic(V) adsorption reactions on synthetic birnessite. Environ Sci Technol 36(5):976-981

5. Nordstrom DK (2002) Worldwide occurrences of arsenic in ground water. Science 296(5576):2143-2145

6. Smedley PL, Kinniburgh DG (2002) A review of the source, behaviour and distribution of arsenic in natural waters. Appl Geochem 17(5):517-568

7. Yoon S-H, Lee JH, Oh S, Yang JE (2008) Photochemical oxidation of As(III) by vacuum-UV lamp irradiation. Water Res 42(13):3455-3463

8. Leng W, Li X, Fei H, Zhang J, Cao C (2011) Comment on "photocatalytic oxidation mechanism of $\mathrm{As}(\mathrm{III})$ on $\mathrm{TiO}_{2}$ : unique role of $\mathrm{As}(\mathrm{III})$ as a charge recombinant species". Environ Sci Technol 45(5):2028-2029

9. Sharma VK, Dutta PK, Ray AK (2007) Review of kinetics of chemical and photocatalytical oxidation of arsenic(III) as influenced by pH. J Environ Sci Health, Part A 42(7):997-1004

10. Yoon S-H, Oh S-E, Yang JE, Lee JH, Lee M, Yu S et al (2009) $\mathrm{TiO}_{2}$ photocatalytic oxidation mechanism of As(III). Environ Sci Technol 43(3):864-869

11. Ferguson $\mathrm{M}_{1}$ Hering J (2006) $\mathrm{TiO}_{2}$-photocatalyzed As(III) oxidation in a fixed-bed flow-through reactor. Environ Sci Technol 40(13):4261-4267

12. Bhandari N, Reeder RJ, Strongin DR (2011) Photoinduced oxidation of arsenite to arsenate on ferrihydrite. Environ Sci Technol 45(7):2783-2789

13. Bhandari N, Reeder RJ, Strongin DR (2012) Photoinduced oxidation of arsenite to arsenate in the presence of goethite. Environ Sci Technol 46(15):8044-8051

14. Fischel MHH, Fischel JS, Lafferty BJ, Sparks DL (2015) The influence of environmental conditions on kinetics of arsenite oxidation by manganese-oxides. Geochem Trans 16(1):1-10

15. Smith PF, Deibert BJ, Kaushik S, Gardner G, Hwang S, Wang H et al (2016) Coordination geometry and oxidation state requirements of cornersharing $\mathrm{MnO}_{6}$ octahedra for water oxidation catalysis: an investigation of manganite ( $\gamma-\mathrm{MnOOH})$. ACS Catal 6(3):2089-2099

16. Villalobos M, Toner B, Bargar J, Sposito G (2003) Characterization of the manganese oxide produced by Pseudomonas putida strain MnB1. Geochim Cosmochim Acta 67(14):2649-2662

17. Burns RG, Burns VM (1977) The mineralogy and crystal chemistry of deep-sea manganese nodules a polymetallic resource of the twenty-first century. Philos Trans R Soc Lond A 286(1336):283-301

18. Golden DC, Dixon JB, Chen CC (1986) lon exchange, thermal transformations, and oxidizing properties of birnessite. Clays Clay Miner 34(5):511-520

19. Stouff P, Boulegue J (1988) Synthetic 10- $\AA$ and 7- $\AA$ phyllomanganates: their structures as determined by EXAFS. Am Mineral 73(9-10):1162-1169

20. Santelli CM, Webb SM, Dohnalkova AC, Hansel CM (2011) Diversity of Mn oxides produced by $\mathrm{Mn}(\mathrm{II})$-oxidizing fungi. Geochim Cosmochim Acta 75(10):2762-2776
21. Webb SM, Tebo BM, Bargar JR (2005) Structural characterization of biogenic Mn oxides produced in seawater by the marine Bacillus sp. strain SG-1. Am Mineral 90(8-9):1342

22. Fleeger CR, Heaney PJ, Post JE (2013) A time-resolved X-ray diffraction study of Cs exchange into hexagonal H-birnessite. Am Mineral 98(4):671

23. Nesbitt HW, Canning GW, Bancroft GM (1998) XPS study of reductive dissolution of $7 \AA$-birnessite by $\mathrm{H}_{3} \mathrm{AsO}_{3}$, with constraints on reaction mechanism. Geochim Cosmochim Acta 62(12):2097-2110

24. Moore JN, Walker JR, Hayes TH (1990) Reaction scheme for the oxidation of arsenic(III) to arsenic(V) by birnessite. Clays Clay Miner 38(5):549-555

25. Power LE, Arai Y, Sparks DL (2005) Zinc adsorption effects on arsenite oxidation kinetics at the birnessite-water interface. Environ Sci Technol 39(1):181-187

26. Scott MJ, Morgan JJ (1995) Reactions at oxide surfaces. 1. Oxidation of As(III) by synthetic birnessite. Environ Sci Technol 29(8):1898-1905

27. Tournassat C, Charlet L, Bosbach D, Manceau A (2002) Arsenic(III) oxidation by birnessite and precipitation of manganese(II) arsenate. Environ Sci Technol 36(3):493-500

28. Yang G, Zhao X, Qi J (2003) Advances in the marine photochemistry of some important transition metal elements. J Ocean Univ Qingdao 2(1):79-84

29. Huerta-Diaz MA (2006) Influence of light on the adsorption of copper from seawater onto goethite and birnessite. Bull Environ Contam Toxicol 77(1):60-66

30. Jokic A, Frenkel Al, Huang PM (2001) Effect of light on birnessite catalysis of the Maillard reaction and its implication in humification. Can J Soil Sci 81(3):277-283

31. Kwon KD, Refson K, Sposito G (2009) On the role of Mn(IV) vacancies in the photoreductive dissolution of hexagonal birnessite. Geochim Cosmochim Acta 73(14):4142-4150

32. Xyla AG, Sulzberger B, Luther GW, Hering JG, Van Cappellen P, Stumm W (1992) Reductive dissolution of manganese(III, IV) (hydr)oxides by oxalate: the effect of $\mathrm{pH}$ and light. Langmuir 8(1):95-103

33. Pinaud BA, Chen Z, Abram DN, Jaramillo TF (2011) Thin films of sodium birnessite-type $\mathrm{MnO}_{2}$ : optical properties, electronic band structure, and solar photoelectrochemistry. J Phys Chem C 115(23):11830-11838

34. Sherman DM (2005) Electronic structures of iron(III) and manganese(IV) (hydr)oxide minerals: thermodynamics of photochemical reductive dissolution in aquatic environments. Geochim Cosmochim Acta 69(13):3249-3255

35. Sakai N, Ebina Y, Takada K, Sasaki T (2005) Photocurrent generation from semiconducting manganese oxide nanosheets in response to visible light. J Phys Chem B 109(19):9651-9655

36. Yang DS, Wang MK (2002) Syntheses and characterization of birnessite by oxidizing pyrochroite in alkaline conditions. Clays Clay Miner 50(1):63-69

37. Yang DS, Wang MK (2001) Syntheses and characterization of well-crystallized birnessite. Chem Mater 13(8):2589-2594

38. Lopano CL, Heaney PJ, Post JE, Hanson J, Komarneni S (2007) Timeresolved structural analysis of $\mathrm{K}$ - and $\mathrm{Ba}$-exchange reactions with synthetic Na-birnessite using synchrotron X-ray diffraction. Am Mineral 92:380-387

39. Drits VA, Silvester E, Gorshkov Al, Manceau A (1997) Structure of synthetic monoclinic Na-rich birnessite and hexagonal birnessite: I. Results from $x$-ray diffraction and selected-area electron diffraction. Am Mineral 82(9-10):946-961

40. Silvester E, Manceau A, Drits VA (1997) Structure of synthetic monoclinic Na-rich birnessite and hexagonal birnessite: II. Results from chemical studies and EXAFS spectroscopy. Am Mineral 82(9-10):962-978

41. Prieto O, Del Arco M, Rives V (2003) Characterisation of $\mathrm{K}, \mathrm{Na}$, and Li birnessites prepared by oxidation with $\mathrm{H}_{2} \mathrm{O}_{2}$ in a basic medium. Ion exchange properties and study of the calcined products. J Mater Sci 38(13):2815-2824

42. Prieto O, del Arco M, Rives V (2003) Structural evolution upon heating of sol-gel prepared birnessites. Thermochim Acta 401(2):95-109

43. Hansen LD, Richter BE, Rollins DK, Lamb JD, Eatough DJ (1979) Determination of arsenic and sulfur species in environmental samples by ion chromatography. Anal Chem 51(6):633-637

44. Zhang J, Nosaka Y (2014) Mechanism of the $\mathrm{OH}$ radical generation in photocatalysis with $\mathrm{TiO}_{2}$ of different crystalline types. J Phys Chem C 118(20):10824-10832 
45. Nakabayashi Y, Nosaka $Y$ (2013) OH radical formation at distinct faces of rutile $\mathrm{TiO}_{2}$ crystal in the procedure of photoelectrochemical water oxidation. J Phys Chem C 117(45):23832-23839

46. Yildiz G, Demiryürek AT (1998) Ferrous iron-induced luminol chemiluminescence: a method for hydroxyl radical study. J Pharmacol Toxicol Methods 39(3):179-184

47. Cohn CA, Laffers R, Schoonen MAA (2006) Using yeast RNA as a probe for generation of hydroxyl radicals by earth materials. Environ Sci Technol 40(8):2838-2843

48. Ginder-Vogel M, Landrot G, Fischel J, Sparks D (2009) Quantification of rapid environmental redox processes with quick-scanning $x$-ray absorption spectroscopy (Q-XAS). Proc Nat Acad Sci 106(38):16124-16128

49. Khalid S, Caliebe W, Siddons P, So I, Clay B, Lenhard T (2010) Quick extended $x$-ray absorption fine structure instrument with millisecond time scale, optimized for in situ applications. Rev Sci Instrum 81(1):015105

50. Bhandari N, Hausner DB, Kubicki JD, Strongin DR (2010) Photodissolution of ferrihydrite in the presence of oxalic acid: an in situ ATR-FTIR/DFT study. Langmuir 26(21):16246-16253

51. Lafferty BJ, Ginder-Vogel M, Sparks DL (2010) Arsenite oxidation by a poorly crystalline manganese-oxide 1: stirred-flow experiments. Environ Sci Technol 44(22):8460-8466

52. Villalobos M, Escobar-Quiroz IN, Salazar-Camacho C (2014) The influence of particle size and structure on the sorption and oxidation behavior of birnessite: I. Adsorption of As(V) and oxidation of As(III). Geochim Cosmochim Acta 125:564-581

53. Zhu M, Paul KW, Kubicki JD, Sparks DL (2009) Quantum chemical study of arsenic(III, V) adsorption on Mn-oxides: implications for arsenic(III) oxidation. Environ Sci Technol 43(17):6655-6661

54. Lafferty BJ, Ginder-Vogel M, Zhu M-Q, Livi KJT, Sparks DL (2010) Arsenite oxidation by a poorly crystalline manganese-oxide 2: results from $\mathrm{x}$-ray absorption spectroscopy and $\mathrm{x}$-ray diffraction. Environ Sci Technol 44(22):8467-8472

55. Perez-Benito JF (2002) Reduction of colloidal manganese dioxide by manganese(II). J Colloid Interface Sci 248(1):130-135
56. Ling FT, Heaney PJ, Post JE, Gao X (2015) Transformations from triclinic to hexagonal birnessite at circumneutral $\mathrm{pH}$ induced through $\mathrm{pH}$ control by common biological buffers. Chem Geol 416:1-10

57. Peacock CL, Sherman DM (2007) Sorption of Ni by birnessite: equilibrium controls on $\mathrm{Ni}$ in seawater. Chem Geol 238(1-2):94-106

58. Kim K, Yoon H-I, Choi W (2012) Enhanced dissolution of manganese oxide in ice compared to aqueous phase under illuminated and dark conditions. Environ Sci Technol 46(24):13160-13166

59. Marafatto FF, Strader ML, Gonzalez-Holguera J, Schwartzberg A, Gilbert B, Peña J (2015) Rate and mechanism of the photoreduction of birnessite $\left(\mathrm{MnO}_{2}\right)$ nanosheets. Proc Nat Acad Sci 112(15):4600-4605

60. Pham AL-T, Doyle FM, Sedlak DL (2012) Inhibitory effect of dissolved silica on $\mathrm{H}_{2} \mathrm{O}_{2}$ decomposition by iron(III) and manganese(IV) oxides: implications for $\mathrm{H}_{2} \mathrm{O}_{2}$-based in situ chemical oxidation. Environ Sci Technol 46(2):1055-1062

61. Elprince AM, Mohamed WH (1992) Catalytic decomposition kinetics of aqueous hydrogen peroxide and solid magnesium peroxide by birnessite. Soil Sci Soc Am J 56(6):1784-1788

62. Petigara BR, Blough NV, Mignerey AC (2002) Mechanisms of hydrogen peroxide decomposition in soils. Environ Sci Technol 36(4):639-645

63. Ryu J, Choi W (2006) Photocatalytic oxidation of arsenite on $\mathrm{TiO}_{2}$ : understanding the controversial oxidation mechanism involving superoxides and the effect of alternative electron acceptors. Environ Sci Technol 40(22):7034-7039

64. Yoon S-H, Lee JH (2005) Oxidation mechanism of As(III) in the UV/TiO2 system: evidence for a direct hole oxidation mechanism. Environ Sci Technol 39(24):9695-9701

65. Xu T, Kamat PV, O'Shea KE (2005) Mechanistic evaluation of arsenite oxidation in $\mathrm{TiO}_{2}$ assisted photocatalysis. J Phys Chem A 109(40):9070-9075

\section{Submit your manuscript to a SpringerOpen ${ }^{\circ}$ journal and benefit from:}

- Convenient online submission

- Rigorous peer review

- Immediate publication on acceptance

- Open access: articles freely available online

- High visibility within the field

- Retaining the copyright to your article

Submit your next manuscript at springeropen.com 